\title{
Alleviation of arsenic accumulation in rice by applying silicon-rich rice husk residues in Bangladesh soil
}

\author{
A. Mamud ${ }^{1}$, B. Saha ${ }^{2}$, S. A. Hossain ${ }^{3}$ and M. T. A. Chowdhury ${ }^{1 \%}$ \\ ${ }^{1}$ Department of Soil, Water and Environment, University of Dhaka, Dhaka-1000, Bangladesh \\ ${ }^{2}$ Bangladesh Council of Scientific and Industrial Research, Dhaka-1205, Bangladesh \\ ${ }^{3}$ Eastern University, Dhanmondi, Dhaka-1205, Bangladesh
}

Received: 27 May 2021

Revised: 14 June 2021

Accepted: 28 June 2021

DOI: https://doi.org/10.3329/bjsir.v56i3.55967

\begin{abstract}
While the accumulation of arsenic in rice (Oryza sativa L.) has been highlighted as a major concern in Bangladesh, sustainable measures are critically needed to reduce the uptake of arsenic by rice plants. In the present study, a pot-experiment was conducted using a Boro rice variety (BRRI dhan-29) in two geomorphologically different soils from Holocene floodplains and Pleistocene terraces, in which silicon-rich fresh rice husk (FRH) and rice husk ash (RHA) were applied, as silicon fertilisers, in the soils at the rate of $1 \%(\mathrm{w} / \mathrm{w})$ of rice residue:soil.In the Holocene floodplain soils, the application of FRH was found to decrease arsenic in grain, husk and straw by 42,56 and $51 \%$, respectively, whereas the soil incorporation of RHA decreased arsenic in grain, husk and straw by $26,37.5$ and $36 \%$, respectively. In the Pleistocene terrace soils, the application of FRH reduced the grain, husk and straw arsenic by 38,38 and $44 \%$, respectively, whereas the RHA decreased the grain, husk and straw arsenic by 26,30 and $29 \%$, respectively. Fresh rice husk was found to be more effective in alleviating arsenic accumulation in rice than RHA. In both the Holocene floodplain and Pleistocene terrace soils, the grain concentrations of calcium, phosphorus, silicon, and zinc were found to be increased with the decrease of arsenic in the grain due to the use of FRH and RHA. The present study suggests that silicon-rich rice husk residue scan be used as silicon fertilisers to reduce arsenic accumulation in rice in Bangladesh.
\end{abstract}

Keywords: Rice; Arsenic; Silicon; Rice husk; Husk ash

\section{Introduction}

Arsenic contamination of paddy cultivated soils irrigated with arsenic laden groundwater in Bangladesh is well documented (Meharg and Rahman, 2003; Huq and Naidu, 2003; Chowdhury et al., 2017). Rice crops grown in the arsenic enriched soils can accumulate elevated concentrations of arsenic into the plant parts, particularly into the grains (Meharg et al., 2001; Abedin et al., 2002; Williams et al., 2006; Huq 2008). Rice accumulates an order of magnitude higher arsenic concentration in its grain compared to other cereals (Williams et al., 2007). The high concentration of arsenic in rice grain is due to a number of factors. Arsenic in flooded paddy soils is more available compared to non-flooded soils, as it is present predominantly as arsenite, which is more mobile and toxic compared to arsenate (Xu et al., 2008; Takahashi et al., 2004). Additionally, rice is a high accumulator of silicon (Ma et al., 2001a; Ma et al., 2001b), which is a non-toxic and beneficial element for rice, comprising up to ten percent of the dry matter in rice husk and straw being much higher than other mineral nutrients (Epstein, 1994; 1999; 2009). This is important as it has been shown that arsenic is taken up by the same transporter genes (Lsi1 and Lsi2), which is responsible for the accumulation of silicon from the soil (Ma et al., 2006; Ma et al., 2008). Rice is the staple food of one hundred and sixty million people in Bangladesh, and seventy percent of total calorific intake by the population is from rice (GRiSP, 2013).

\footnotetext{
*Corresponding author e-mail: mta.chowdhury@du.ac.bd
} 
It indicates that rice dependent diets, such as those of Bangladeshi people, pose a serious issue for human arsenic intake (Schoof et al., 1999). Therefore, developing a sustainable strategy to alleviate arsenic accumulation in rice, thereby improving the quality of food and human health across the world is indispensable.

Use of silicon is an emerging method to reduce arsenic uptake by rice (Ma et al., 2008; Seyfferth et al., 2016; Limmer et al., 2018). Dissolved and plant-available silicon in soil can improve the yield and quality of rice by reducing arsenic uptake/toxicity (Bogdan and Schenk, 2008; Li et al., 2009; Seyfferth and Fendorf, 2012) and the severity of fungal diseases (Datnoff et al., 2001; Seebold et al., 2001). Increasing plant-available silicon in the porewater of well-weathered, silicon-depleted rice soils (Savant et al.,1997) can decrease grain arsenic as a result of competitive interactions between silicon (silicic acid) and arsenic (arsenite) for plant uptake and adsorption onto soil solids (Luxton et al., 2006; Li et al., 2009; Bogdan and Schenk, 2008; Seyfferth and Fendorf, 2012). However, the source of silicon matters, as various silicon sources affect rice arsenic uptake differently. Silicon-rich materials that increase porewater silicon in high concentrations, such as silica gel, decrease grain arsenic (Li et al., 2009; Seyfferth and Fendorf, 2012), whereas silicon-rich materials with a low silicon solubility, such as diatomaceous earth, may increase grain arsenic (Seyfferth and Fendorf, 2012). The application of silica fertilisers such as calcium silicate $\left(\mathrm{CaSiO}_{3}\right)$ in paddies may reduce arsenic concentration in rice (Guo et al., 2005; Guo et al., 2007), but these may contain toxic trace metals which can negatively affect rice yield and quality (Gu et al., 2011). While rice farmers in developing countries, like in Bangladesh, may have limited access to synthetic silicon fertilisers, agronomic practices like incorporation of silicon-rich rice residues such as rice straw and rice husk can be a holistic approach to reduce arsenic in rice grain (Ma et al., 2014; Seyfferth et al., 2016; Penido et al., 2016; Limmer et al., 2018). Incorporation of silicon-rich rice straw has been reported to increase arsenic uptake by rice in grain (Ma et al., 2014), whereas incorporation of silicon-rich rice husk and husk ash decreased arsenic accumulation in rice grain (Penido et al., 2016; Seyfferth et al., 2016). Rice husk contains less arsenic and labile carbon and provides more silicon to soil porewater compared to rice straw which releases more arsenic and less silicon in soil porewater than fresh husk or huskash (Penido et al., 2016). In addition, incorporation of rice husk generates less methane emissions, which is a potential greenhouse gas, from rice paddies than incorporation of straw (Penido et al., 2016; Gutekunst et al., 2017). Therefore, rice husk is advantageous over rice straw as a sustainable solution to mitigate arsenic contamination in rice worldwide. However, the performance of the silicon-rich amendments relative to different rice varieties as well as different soil types in different geographic regionsneeds to be better understood.

Bangladesh has three major geomorphological units (Brammer, 1996; Huq and Shoaib, 2013). These are hill, terrace, and floodplain areas. The uplifted terrace areas are of Pleistocene age, and the floodplains are of Holocene age. These geomorphological units are related to the parent geological formations, and they are also characterized by land topography and age of the soil formation through sediment deposition over time (Brammer, 1996). Chowdhury et al. (2017) demonstrated that the Pleistocene terrace paddy soils were generally low in the concentrations of a range of elements, including arsenic and essential macro-and micro-nutrient elements, compared to the Holocene floodplain paddy soils. Provided that the mobilityand biogeochemistry of arsenic in the geomorphologically different paddy soils of Bangladesh are highly and inherently variable (Chowdhury et al., 2017; Chowdhury et al., 2018), it is indeed important to investigate the potential of silicon fertilisation in reducing arsenic accumulation in rice grown in the different soil types of Bangladesh.

In the present study, we evaluated the effects of silicon-rich rice husk residues, both fresh husk and husk ash, amendments on the accumulation of arsenic, calcium, phosphorus,silicon, and zinc in rice (BRRI dhan 29 variety) grown in two geomorphologically and biogeochemically different soils of Bangladesh, the Holocene floodplain and Pleistocene terrace soils, which were also naturally variable in arsenic concentrations.

\section{Materials and methods}

\section{Collection and processing of soil samples}

Bulk soil samples were collected from 2 geomorphologically different regions of Bangladesh: (i) the Holocene floodplain; the soils belonged to the physiographic region of Meghna Estuarine floodplain located at Baidder Bazar union, Sonargaon upazila, Narayanganj district, $23^{\circ} 39^{\prime} \mathrm{N}$ and $90^{\circ}$ $37^{\prime} \mathrm{E}$, and (ii) the Pleistocene terrace; the soils belonged to the physiographic region of Madhupur Tract, located at Bhawal Rajabari union, Sreepur upazila, Gazipur district, $24^{\circ}$ 06' 35.96" N and 90²9' 56.89" E. The collected soil samples were processed and prepared for pot experiment and background analysis following the procedures described in Chowdhury et al. (2010). 


\section{Pot culture experiment}

A pot culture experiment was conducted using a lowland crop, rice (Oryza sativa L., BRRI dhan 29 variety) and the soils collected from the geomorphologically different areas of Holocene floodplain and Pleistocene terrace. In order to determine the impact of silicon-rich ricehusk incorporation to soil on arsenic uptake by rice, powered fresh rice husk (FRH, obtained from a rice millin Savar, Dhaka) and rice husk ash (RHA, obtained by combustion of the same rice husk) were utilised as silicon amendment treatment at a rate of $1 \%(\mathrm{w} / \mathrm{w})$ of rice residue:soil, as recommended by Penido et al .(2016), although this level of amendment could be higher than feasible for application on a large scale considering the production of husk per crop cycle (Seyfferth et al. 2016). Rice grown in the soils amended with the silicon-rich rice residues were compared to non-amended controls. All the treatments and non-amended control were conducted in triplicates. Therefore, a total of 18 pots (earthen pots of $8 \mathrm{~kg}$ in size, having no hole at the bottom, with $5 \mathrm{~kg}$ of air-dried and $5 \mathrm{~mm}$ sieved soil samples) were used in the pot experiment. The FRH and RHA (50 g) were gently mixed by hand into the soil in the pots 7 days prior to the plantation of rice seedlings collected from a farmer's field, and the pots were flooded to $4 \mathrm{~cm}$ above the soil surface using distilled water. All the pots were placed in a net-house in a randomized arrangement. Transplantation of the rice seedlings and culture of the plants during the rice growing period were done according to the protocols described in Chowdhury et al. (2010).

\section{Collection and processing of plants and residual soils}

Rice plants were harvested after 110 days of seedling transplantation. At harvest, the rice plantsamples (separated into 3 parts: roots, straw and grains) and the residual soil samples were collected and processed manually by following the procedures described in Chowdhury et al. (2010).

\section{Chemical analysis}

The initial and residual soils, and the FRH and RHA were analyzed for $\mathrm{pH}$, organic carbon, arsenic, calcium, nitrogen, phosphorus, potassium, silicon, sulfur, and zinc, and the rice grain, husk, and straw were analyzed for total arsenic, calcium, phosphorus, silicon, and zinc following the analytical procedures described in Huq and Alam (2005). For the analysis of the elements, the soils and plant samples were digested using aqua regia (a mixture of nitric acid and hydrochloric acid in the ratio of $1: 3$ ). The concentrations of phosphorus in the soils and plant samples were determined colorimetrically using a spectrophotometer. The concentrations of arsenic, calcium, silicon, and zincin the soils and plant samples were determined using atomic absorption spectrometer (Shimadzu AA-7000 was used for analysing arsenic and silicon, and Varian AA-240 was used for analysing calcium and zinc). The quality control/quality assurance of the analysis was maintained following the standard procedure.

\section{Statistical analysis}

Statistical analyses were performed using the statistical software Minitab v.19 (State College PA) and SigmaPlot v.14 (Systat Software Inc., CA). The data were checked for normality and were transformed prior to statistical analysis where appropriate.

\section{Results and discussion}

\section{Background properties of the soil and silicon-rich rice residues}

The concentrations of arsenic, calcium, nitrogen, organic carbon, phosphorus, and zinc werefound to be higher in the Holocene floodplain soil compared to the Pleistocene terrace soil, which had higher concentrations of potassium, silicon and sulfur (Table I). The paddy soils of the Holocene floodplains have been found to be generally higher in a range of geochemical elements including arsenic compared to the Pleistocene terracesoils across Bangladesh (Chowdhury et al. 2017). Higher concentrations and mobilization of arsenic in the Holocene floodplain soils due to enhanced influence of the pedoenvironmental properties in the soils have also been reported by Martin et al. $(2014 ; 2015)$. Silicon is the most abundant element in soil (Kabata-Pendias, 2011); however, silicon in the paddy soil svaries with the amount of crop residues remaining in the field that adds large amounts of silicon-rich phytoliths in the soils (Wilding, 1967; Parr and Sullivan, 2005; Wickramasinghe and Rowell, 2006).

The $\mathrm{pH}$ and the concentrations of all the elements analysed, except sulfur, were observed to be higher in the RHA compared to in the FRH (Table I). This was perhaps due to the fact that when the rice husks were burnt, the strongly bound fractions of the elements were released and came into the solution when extracted. Igwebike-Ossi (2017) also found lower concentrations of 13 different elements in fresh rice husks than in rice husk ash, which could be attributed to the presence of greater amounts of water and lignocellulosic components in fresh rice husk giving it a larger weight and volume of materials than in the husk ash (Mansaray and Ghaly, 1998; Stroevena et al., 1999). When these components were removed during combustion, the reduction in weight and volume of the rice husk ash residue gave rise to higher concentrations of the elements in the husk ash. 
Table I. Background properties of the initial soil and silicon-rich rice residues

\begin{tabular}{|c|c|c|c|c|}
\hline \multirow[b]{2}{*}{ Soil properties } & \multicolumn{4}{|c|}{ Value } \\
\hline & $\begin{array}{l}\text { Holocene floodplain } \\
\text { soil }\end{array}$ & $\begin{array}{c}\text { Pleistocene terrace } \\
\text { soil }\end{array}$ & Fresh rice husk & Rice husk ash \\
\hline $\mathrm{pH}$ & 6.86 & 5.61 & 7.10 & 7.10 \\
\hline Organic carbon $(\%)$ & 1.25 & 0.84 & 6.00 & - \\
\hline Organic matter $(\%)$ & 2.18 & 1.47 & 10.32 & - \\
\hline Arsenic $\left(\mathrm{mg} \mathrm{kg}^{-1}\right)$ & 8.32 & 5.55 & 1.55 & 1.73 \\
\hline Calcium (mg kg $\left.{ }^{-1}\right)$ & 18110 & 8310 & 2273 & 3706 \\
\hline Nitrogen (\%) & 0.16 & 0.09 & 1.04 & 1.15 \\
\hline Phosphorus (\%) & 0.06 & 0.03 & 0.004 & 0.63 \\
\hline Potassium (\%) & 0.27 & 0.34 & 0.90 & 1.71 \\
\hline Silicon (mg kg ${ }^{-1}$ ) & 189 & 268 & 467 & 1800 \\
\hline Sulfur (\%) & 0.05 & 0.06 & 0.12 & 0.10 \\
\hline Zinc $\left(m g \mathrm{~kg}^{-1}\right)$ & 77.75 & 45.45 & 72 & 91 \\
\hline
\end{tabular}
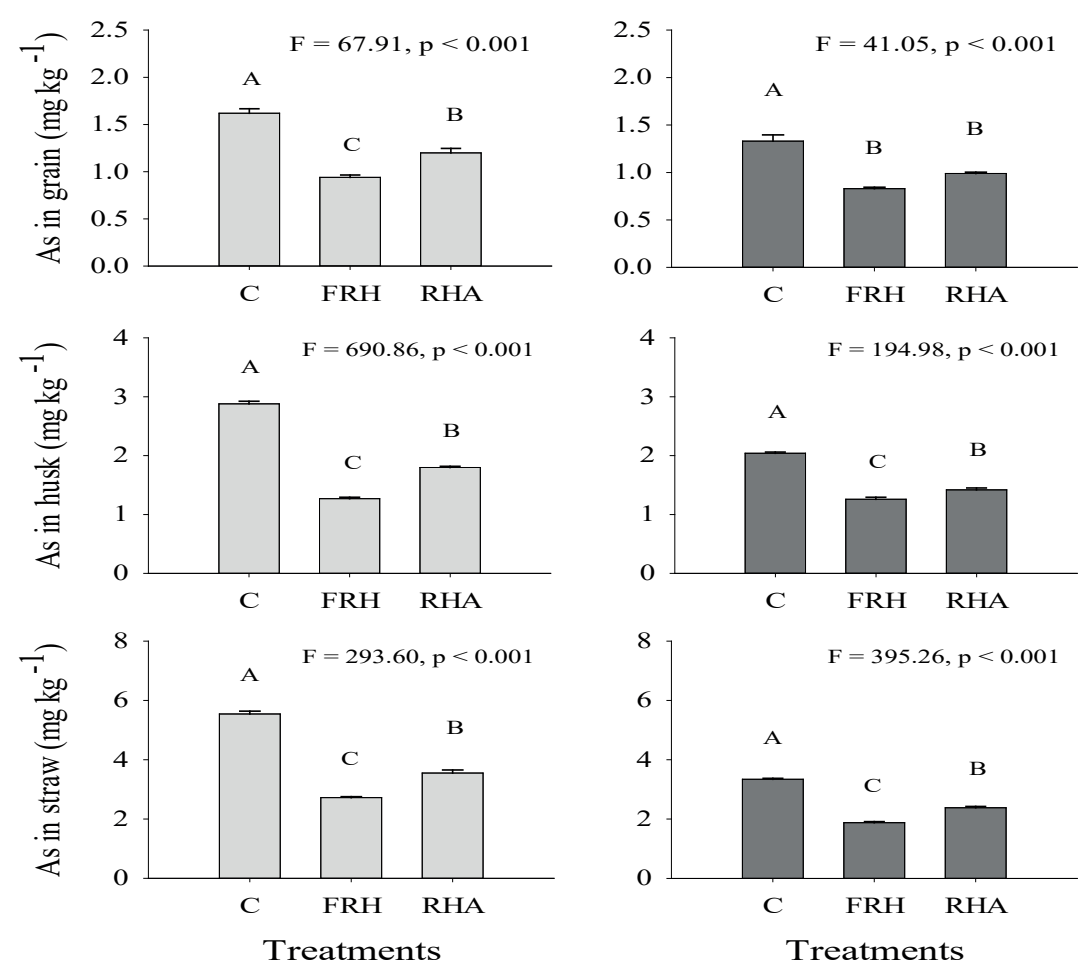

Holocene floodplain soil

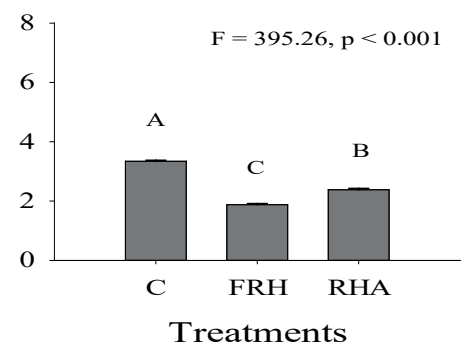

Pleistocene terrace soil

Fig. 1. The concentrations of total arsenic (As) in rice grain, husk, and straw grown in non-amended control (C) and silicon-rich fresh rice husk (FRH) and rice husk ash (RHA) amended Holocene floodplain and Pleistocene terrace soils. One-way analysis of variance was used to compare pair-wise the means of arsenic concentrations in grain, husk and straw individually at each of the treatments (C, FRH and RHA). Treatments that share the same letter (A-C) are not significantly different. The letters indicate Tukey groupings for the treatments with respect to their mean arsenic concentrations in rice grain, husk and straw 
Grain
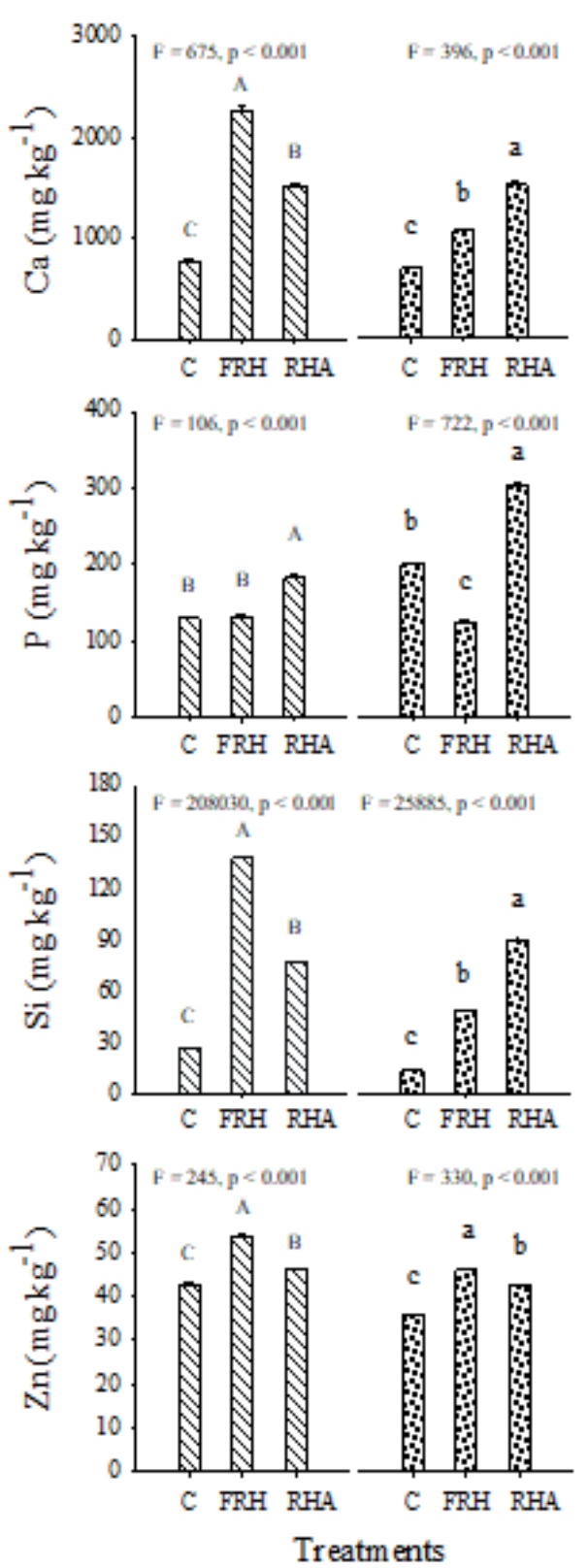

Husk
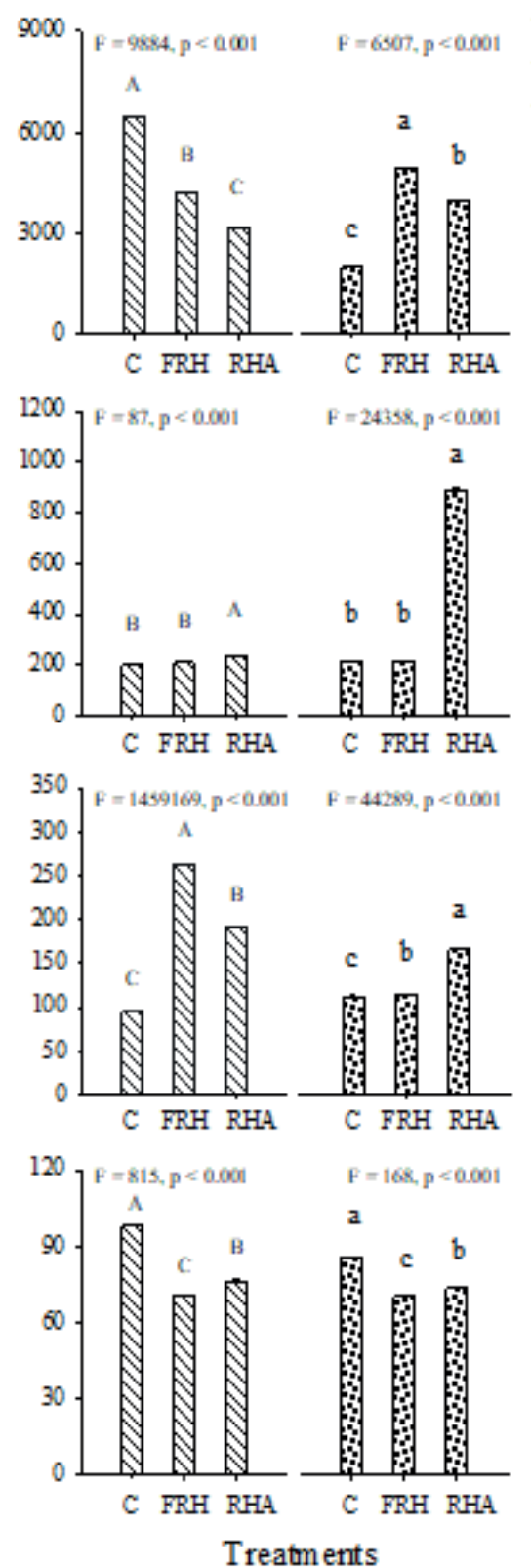

Straw
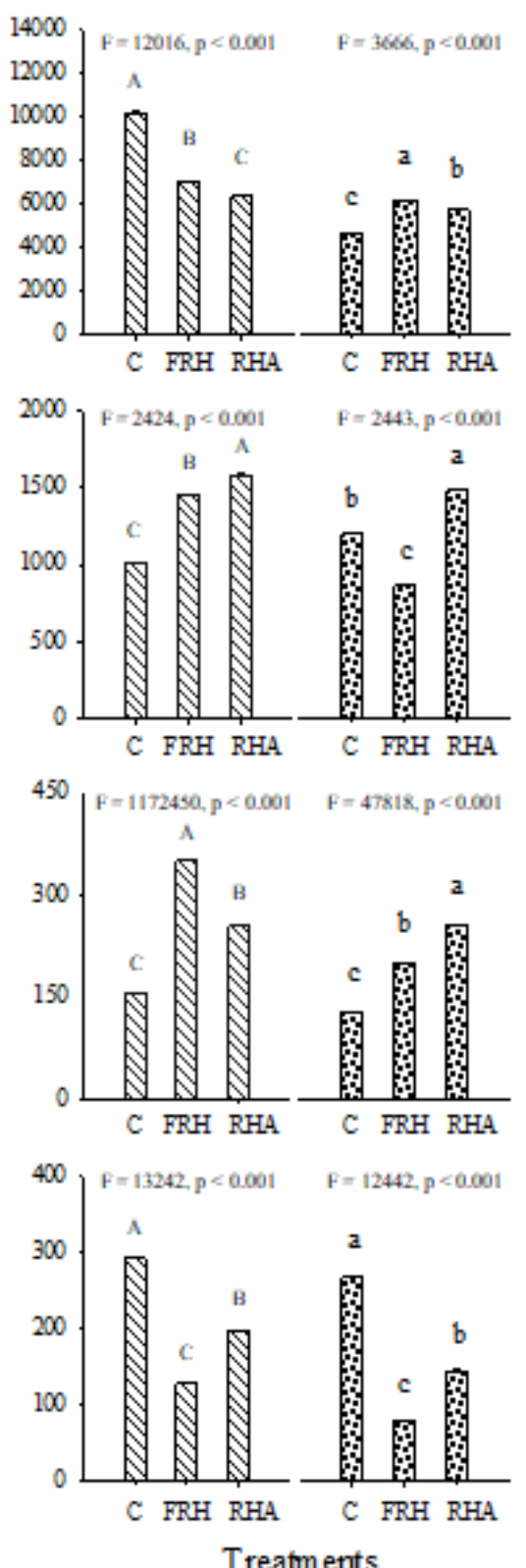

\section{MUIV Holocene floodplain soil}

F5o5s Pleistocene terrace soil

Fig. 2. The concentrations of total calcium (Ca), phosphorus (P), silicon (Si), and zinc (Zn) in rice grain, husk, and straw grown in non-amended control (C) and silicon-rich fresh rice husk (FRH) and rice husk ash (RHA) amended Holocene floodplain and Pleistocene terrace soils. One-way analysis of variance was used to compare pair-wise the means of the concentrations of calcium, phosphorus, silicon and zinc in grain, husk and straw individually at each of the treatments (C, FRH and RHA). Treatments that share the same letter (A - C) are not significantly different. The letters indicate Tukey groupings for the treatments with respect to their mean concentrations of calcium, phosphorus, silicon and zinc in rice grain, husk and straw 
Grain
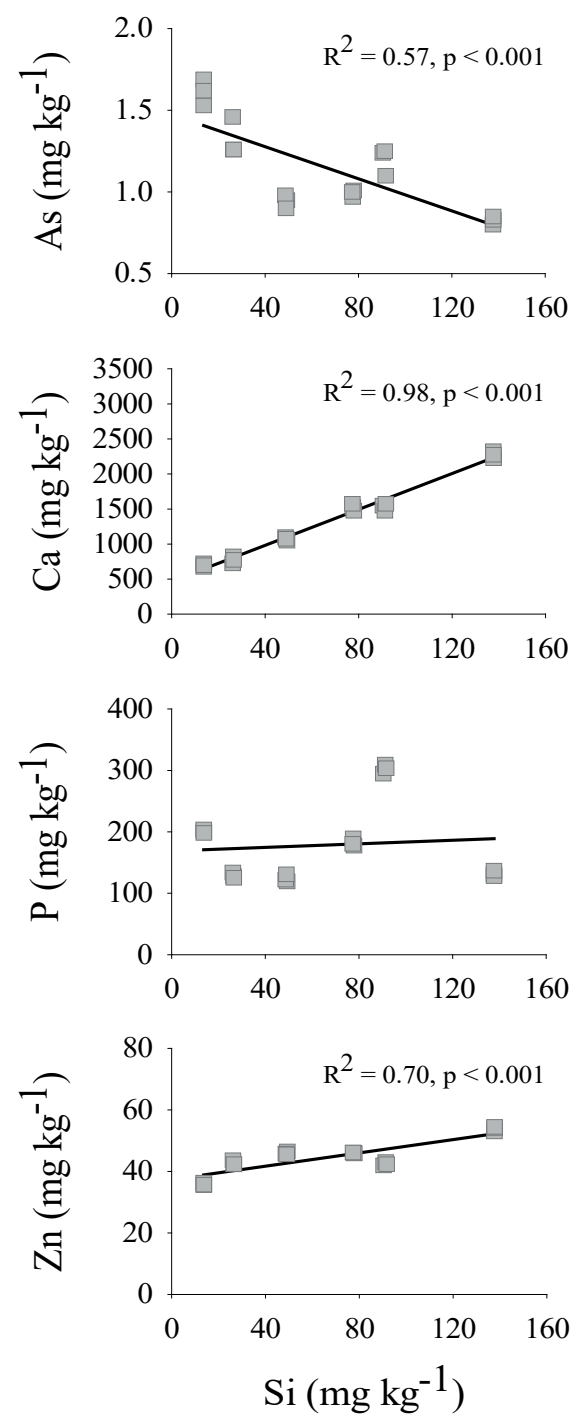

Husk
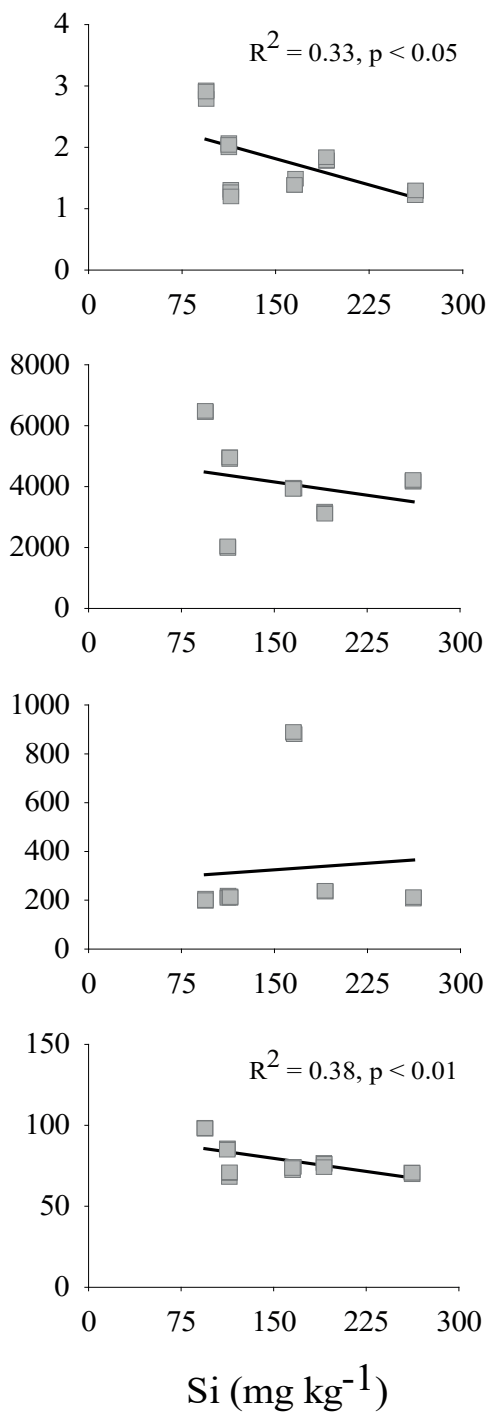

Straw
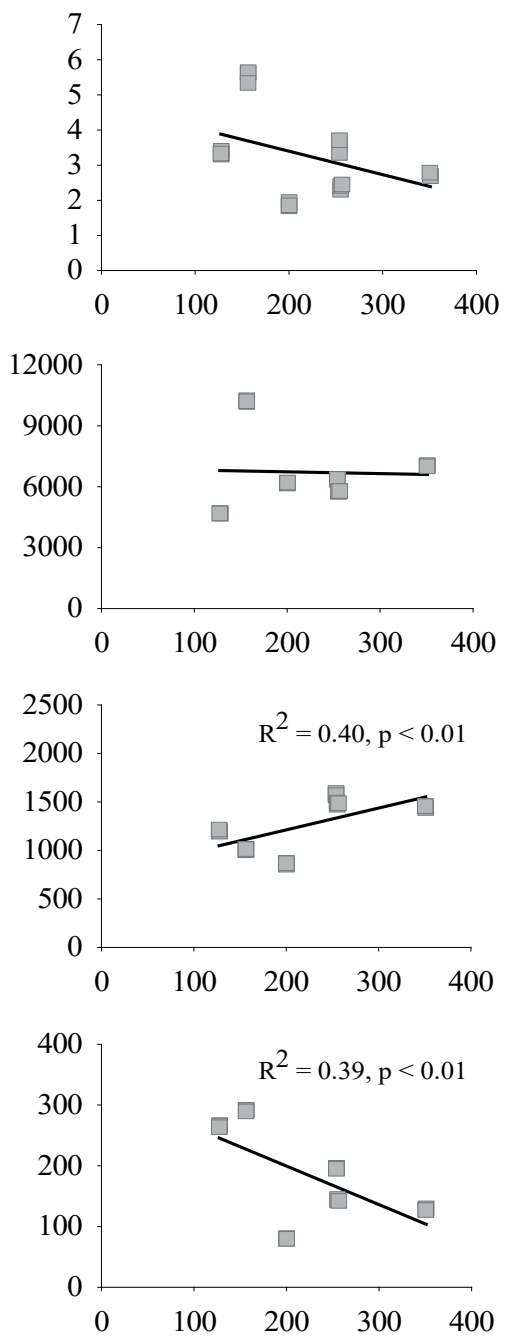

$\mathrm{Si}\left(\mathrm{mg} \mathrm{kg}^{-1}\right)$

Fig. 3. Relationships between silicon (Si) and arsenic (As), calcium (Ca), phosphorus (P), and zinc (Zn) concentrations in rice grain, husk, and straw. The data are irrespective of the soil types (Holocene floodplain and Pleistocene terrace soils) and silicon-rich rice husk residues (fresh rice husk and rice husk ash)

\section{Impacts of silicon fertilisation on rice}

The incorporation of silicon-rich rice husk residues into soil was found to decrease total arsenic in rice grain, husk and straw (Fig. 1). In the Holocene floodplain soils, FRH reduced arsenic in grain, husk and straw by $39-45 \%, 55-58 \%$ and $50-51 \%$, respectively, whereas RHA decreased arsenic in grain, husk and straw by $23-32 \%, 36-38 \%$ and $33-39 \%$, respectively, compared to arsenic concentrations in grain, husk and straw in the non-amended control. In the
Pleistocene terrace soils, FRH reduced arsenic in grain, husk, and straw by $36-40 \%, 36-41 \%$ and $42-45 \%$, respectively, while RHA decreased arsenic in grain, husk and straw by 23 $-27 \%, 27-32 \%$ and $27-31 \%$, respectively, compared to arsenic concentrations in grains, husk and straw in the non-amended control. These indicated that the silicon-rich rice husk residues had potentials to reduce arsenic accumulations in rice plants, the FRH being more efficient in reducing rice arsenic concentrations compared to the RHA. Significant variations in the concentrations of arsenic in grain 
$\left({ }^{A N O V A} \mathrm{~F}=67.91\right.$ and ${ }^{A N O V A} \mathrm{~F}=41.05 ; p<0.001$, respectively, for Holocene floodplain and Pleistocene terrace soils), husk $\left({ }^{A N O V A} \mathrm{~F}=690.86\right.$ and ${ }^{A N O V A} \mathrm{~F}=194.98 ; \mathrm{p}<0.001$, respectively, for Holocene floodplain and Pleistocene terrace soils) and straw $\left({ }^{\text {ANOVA }} \mathrm{F}=293.60\right.$ and ${ }^{A N O V A} \mathrm{~F}=395.26 ; \mathrm{p}<0.001$, respectively, for Holocene floodplain and Pleistocene terrace soils) were observed within the silicon amended and non-amended soils (Fig. 1). The mean concentration of arsenic in rice grain in the FRH amended Holocene floodplain soils was found to be significantly lower than the mean grain arsenic concentration in RHA treated soils, while in the FRH and RHA amended Pleistocene terrace soils, the reduction in grain arsenic was not observed to be statistically significant which could be related to the higher inherent silicon concentration in the Pleistocene terrace soil (Table I). Significant differences in arsenic concentrations in rice grain, husk and straw in response to different silicon amendments (fresh husk, husk ash and calcium silicate) were also observed by Teasley et al. (2017). Seyfferth et al. (2016) also reported reductions in toxic inorganic arsenic in rice grain and straw by $25-50 \%$ and at least $50 \%$, respectively, for 3 different rice cultivars (Oryza sativa L., cv. M206, IR66 and Nipponbare) due to soil incorporation of silicon-rich fresh rice husk residues. This study also found FRH more promising than RHA in reducing the accumulation of inorganic or total arsenic in rice plants, particularly in rice grain. However, charred rice husk was found to be more effective than fresh rice husk in reducing arsenic accumulation in rice plant, which was perhaps due to the presence of more amorphous silica in the char as prepared under lower temperature than ash (Mansaray and Ghaly, 1998; Hanafi and Abo-El-Enein, 1980) that rendered its silicon to be more soluble in the media (Limmer et al., 2018). Teasley et al. (2017) observed about $40 \%$ decrease in grain arsenic concentration due to fresh rice husk amendment, whereas neither calcium silicate nor rice husk ash amendments significantly affected total grain arsenic. Leksungnoen et al. (2019) also reported decreased inorganic grain arsenic by $20-24 \%$ as a result of the incorporation of RHA in soil. Alleviation of arsenic accumulation in rice by using other sources of silicon amendments, such as silica-gel (Li et al., 2009; Seyfferth and Fendorf, 2012; Fleck et al., 2013, Liu et al., 2014) and different silicate minerals as silica fertilisers (Guo et al., 2005; Guo et al., 2007; Tripathia et al., 2013; Wang et al., 2016; Limmer et al., 2018) have also been reported.

The decrease in the concentrations of arsenic,due to silicon-rich FRH and RHA amendments, were found to related to the increase in silicon concentrations in the grain, husk and straw. In the Holocene floodplain soils,
FRH significantly increased $(\mathrm{p}<0.001)$ silicon in grain, husk and straw by $423 \%, 178 \%$ and $124 \%$, respectively, whereas RHA significantly increased $(\mathrm{p}<0.001)$ silicon in grain, husk and straw by $195 \%, 102 \%$ and $62 \%$, respectively, compared to silicon concentrations in grain, husk and straw in the non-amended control (Fig. 2). In the Pleistocene terrace soils, FRH significantly increased $(\mathrm{p}<$ 0.001 ) silicon in grain, husk, and straw by $258 \%, 1.42 \%$ and $57 \%$, respectively, while RHA significantly increased $(\mathrm{p}<0.001)$ silicon in grain, husk and straw by $565 \%, 47 \%$ and $100 \%$, respectively, compared to silicon concentrations in grains, husk and straw in the non-amended control (Fig. 2). Silicon enrichment in the rice plantsdue to silicon fertilization (Seyfferth et al., 2016; Teasley et al., 2017; Cuong et al., 2017) had potentials to decrease arsenic in the rice (Seyfferth et al., 2016; Teasley et al., 2017). The decrease in arsenic in the rice plants due to FRH and RHA amendments in the soils was perhaps regulated bythecompetitive interactions between silicon and arsenic for plant uptake and sorption. The addition of silicon-rich rice husk residues has been reported to increase plant-available silicon in soil porewater, which limitsthe uptake of arsenite by suppressing the expression of the Low silicon 1 (Lsi1) and 2 (Lsi2) genesin roots (Ma et al., 2006; Ma and Yamaji, 2015), and enhance the competition of silicon with arsenite for uptake (Bogdan and Schenk, 2008; Seyfferth and Fendorf, 2012). Thereduced uptake of arsenic by roots, along with the reducedadsorption of arsenic onto soil solids due to enhanced competition with the released silicon from FRH and RHA in soil porewater (Luxton et al., 2006), increases the concentration of arsenic available in soil porewater that may undergo redistribution and remobilisation through irrigation/ monsoon flooding (Roberts et al., 2010) depending on the land topographical condition (Chowdhury et al., 2021). However, the mobilization and retention of arsenic and silicon in paddy soils are also affected by a number of other factors related to the properties and composition of the soil, such as temperature, $\mathrm{pH}$, redox potential, clay and organic matter content, ionic constituents as well as the microbially mediated biogeochemical interactions that control the biogeochemical cycling of the elements in the soil (Bissen and Frimmel, 2003; Mahimairaja et al., 2005; Sommer et al., 2006; Moreno-Jiménez et al., 2012; Pati et al., 2016).

The FRH and RHA amendments significantly $(\mathrm{p}<0.001)$ affected the concentrations of calcium, phosphorus and zinc in rice grain, husk and straw in the Holocene 

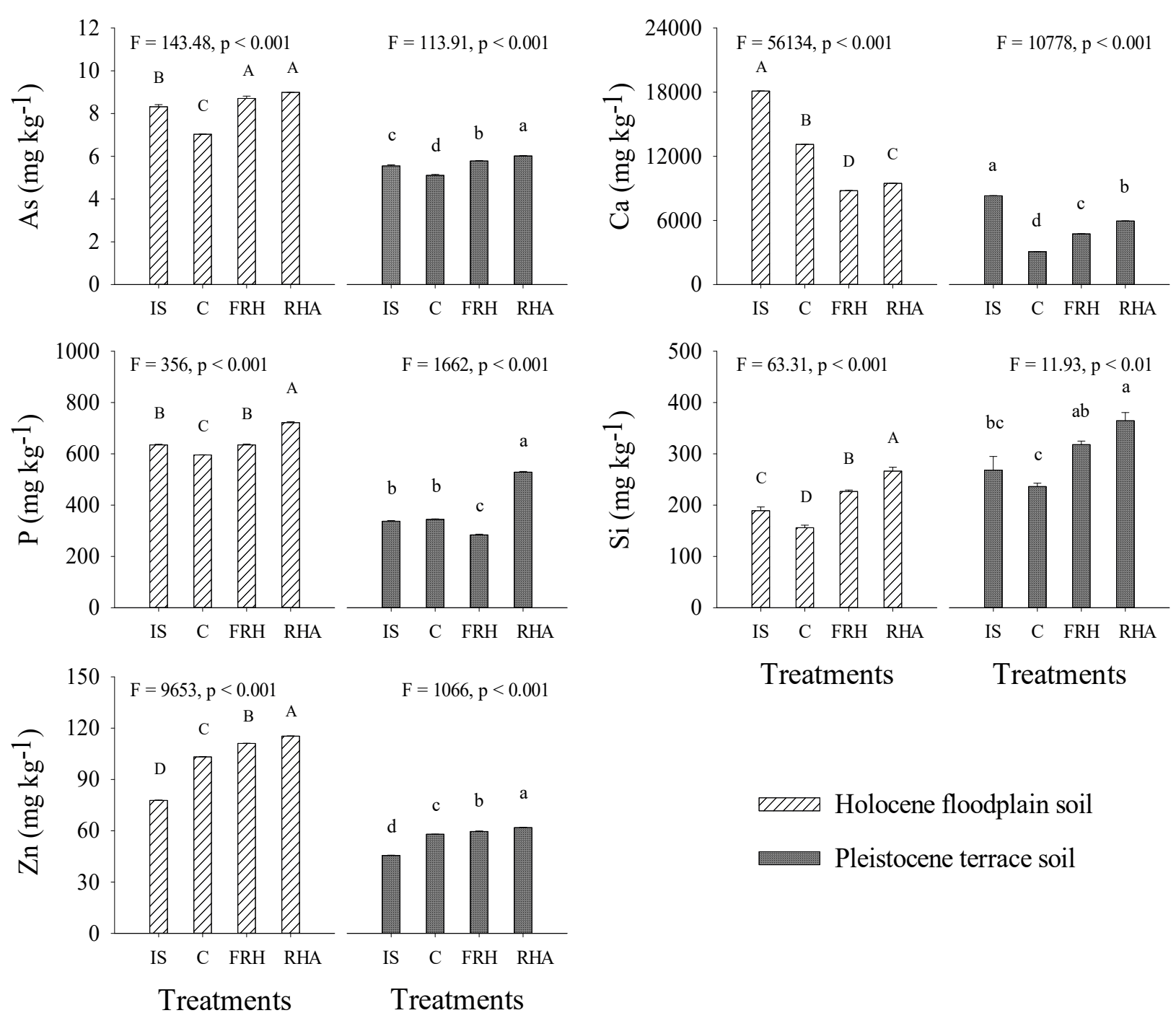

[III/ Holocene floodplain soil

Pleistocene terrace soil

Fig. 4. Concentrations of arsenic (As), calcium (Ca), phosphorus (P), silicon ( $\mathrm{Si})$, and zinc $(\mathrm{Zn})$, in the initial soil (IS) and the post-harvest soils of non-amended control (C) and fresh rice husk (FRH) and rice husk ash (RHA) amended soils of the Holocene floodplain and Pleistocene terrace. One-way analysis of variance was used to compare pare-wise the means of elemental concentrations in the initial and post-harvest soils at each of the treatments (C, FRH, and RHA). Treatments that share the same Tukey letter (A-D, for Holocene floodplain soils; a-d for Pleistocene terrace soils) are not significantly different. The bars are mean \pm standard error of the mean

floodplain and Pleistocene terrace soils (Fig. 2). The mean concentrations of calcium, phosphorus (except for FRH in Pleistocene terrace soil), silicon and zinc in grain were found to be increased in both the FRH and RHA amended soils (Fig. 2). The accumulations of the nutrient elements were enhanced perhaps due to the less arsenic accumulation within the rice grain, as higharsenic concentrations within rice grains impacts negatively on other grain nutrient elements (Williams et al., 2009;
Norton et al., 2010). While the increased silicon concentration in grain had negative impact on grain arsenic, it showed positive relationships with calcium ( ${ }^{\text {inear }}$ regression $\left.\mathrm{R}^{2}=0.98, \mathrm{p}<0.001\right)$ and zinc (linear regression $\mathrm{R}^{2}=0.70$, $\mathrm{p}<0.001$ ) concentrations within the grain (Fig. 3). Increased silicon concentration in soil solution perhaps mobilized the essential nutrients that enhanced the concentrations of the nutrients in rice grain (Cuong et al., 2017; Swain and Rout, 2018). 


\section{Residual concentrations of the elements in soil}

The incorporation of the silicon-rich FRH and RHA was found to increase, in general, the concentrations of all the elements, but calcium, in the post-harvest soils, compared to the concentrations in the initial soil (Fig. 4). The concentrations of arsenic were found to be significantly decreased in the post-harvest soils of the non-amended controls (by 16 and $8 \%$ in the Holocene floodplain and Pleistocene terrace soils, respectively), whereas the concentrations of arsenic were observed to be significantly increased by $4-8 \%$ in the FRH and RHA amended Holocene floodplain and Pleistocene terrace soils. Silicon was also found to be increased by $19-20 \%$ in the FRH amended post-harvest soils, and by $36-41 \%$ in the RHA amended post-harvest soils of the Holocene floodplain and Pleistocene terrace.

\section{Conclusion}

Silicon-rich rice husk residues (fresh huskand husk ash) have potentials to alleviate arsenic accumulation in rice grown in the geomorphologically different soils (Holocene floodplain and Pleistocene terrace soils) of Bangladesh. Soil amendments with rice husk residues could be an effective measure to mitigate arsenic contamination of the food chain in the arsenic affected areas of Bangladesh.

\section{Acknowledgement}

Authors gratefully acknowledge the Centre for Advanced Studies and Research in Biological Sciences, University of Dhaka for funding this project.

\section{References}

Abedin MJ, Cotter-Howells J and Meharg AA (2002), Arsenic uptake and accumulation in rice (Oryza sativa L.) irrigated with contaminated water, Plant Soil 240(2): 311-319.

Bissen M and Frimmel FH (2003), Arsenic-A review. Part I: Occurrence, toxicity, speciation, mobility, Acta Hydrochim. Hydrobiol. 31(1): 9-18. DOI:org/10. 1002/aheh.200390025

Bogdan K and Schenk MK (2008), Arsenic in rice (Oryza sativa L.) related to dynamics of arsenic and silicic acid in paddy soils, Environ. Sci. Technol. 42(21): 7885-7890. DOI: org/10.1021/es801194q
Brammer H (1996), The Geography of the Soils of Bangladesh, The University Press Ltd., Dhaka.

Chowdhury MTA, Meharg AA, Price AH and Norton GJ (2021), Geochemical variability in the soils of Bangladesh as affected by sources of irrigation water and inundation land types, SN Appl. Sci. 3: 256.

Chowdhury MTA, Deacon CM, Steel E, Huq SMI, Paton GI, Price AH, Williams PN, Meharg AA and Norton GJ (2018), Physiographical variability in arsenic dynamics in Bangladeshi soils, Sci. Total Environ. 612: 1365-1372. DOI: org/10.1016/j.scitotenv. 2017.09.030

Chowdhury MTA, Deacon CM, Jones GD, Huq SMI, Williams PN, Hoque AFMM, Winkel LHE, Price AH, Norton GJ and Meharg AA (2017), Arsenic in Bangladeshi soils related to physiographic region, paddy management, and mirco and macro-elemental status, Sci. Total Environ. 590-591: 406-415. DOI: org/10.1016/j.scitotenv.2016.11.191

Chowdhury MTA, NesaL, Kashem MA and Huq SMI (2010), Assessment of the phytoavailability of $\mathrm{Cd}, \mathrm{Pb}$ and $\mathrm{Zn}$ using various extraction procedures, Pedologist 53(3): 80-95. DOI: org/10.18920/pedologist.53.3_80

Cuong TX, UllahH, Datta A and Hanh TC (2017), Effects of silicon-based fertlizer on growth, yield and nutrient uptake of rice in tropical zone of Vietnam, Rice Sci. 24(5): 283-290. DOI: org/10.1016/j.rsci.2017.06.002

Datnoff LE, Seebold KW and Correa-VFJ (2001), The use of silicon for integrated disease management: reducing fungicide applications and enhancing host plant resistance In: Silicon in Agriculture, Eds. Datnoff LE, Snyder GH and Korndorfer GH, Elsevier Science, Amsterdam, pp 171-184, DOI: org/10. 1016/ S09283420(01)80014-8

Epstein E (1994), The anomaly of silicon in plant biology, Proc. Natl. Acad. Sci. 91: 11-17. DOI: org/10. 1073/pnas.91.1.11

Epstein E (1999), Silicon, Annu. Rev. Plant Physiol. Plant Mol. Biol. 50: 641-664.

Epstein E (2009), Plant nutrition, plant stress, and plant silicon, Comp. Biochem. Physiol. A Mol. Integr. Physiol. 153(2): 185-186. DOI: $\quad 10.1016 /$ j.cbpa. 2009. 04.405 
Fleck AT, MattuschJ and Schenk MK (2013), Silicon decreases the arsenic level in rice grain by limiting arsenite transport, J. Plant Nutr. Soil Sci. 176: 785-794. DOI: org/10.1002/jpln.201200440

GRiSP (Global Rice Science Partnership) (2013), Rice Almanac, $4^{\text {th }}$ Ed., International Rice Research Institute, Los Baños, Philippines, pp 121-125.

Gu HH, Qiu H, Tian T, Zhan SS, Deng THB, Chaney RL, Wang SZ, Tang YT, Morel JL and Qiu RL (2011), Mitigation effects of silicon rich amendments on heavy metal accumulation in rice (Oryza sativa L.) planted on multi-metal contaminated acidic soil, Chemosphere 83(9): 1234-1240. DOI:org/10.1016/j.chemosphere. 2011.03.014

Guo W, HouY, Wang S and Zhu YG (2005), Effect of silicate on the growth and arsenate uptake by rice (Oryza sativa L.) seedlings in solution culture, Plant Soil 272: 173-181.

Guo W, Zhu YG, Liu WJ, Liang YC, Geng CN and Wang SG (2007), Is the effect of silicon on rice uptake of arsenate $\left(\mathrm{As}^{\mathrm{V}}\right)$ related to internal silicon concentrations, iron plaque and phosphate nutrition?, Environ. Pollut. 148(1): 251-257. DOI: org/10. 1016/j.envpol.2006.10.021

Gutekunst MY, Vargas R and Seyfferth AL (2017), Impacts of soil incorporation of pre-incubated silica-rich rice residue on soil biogeochemistry and greenhouse gas fluxes under flooding and drying, Sci. Total Environ. 593-594: 134-143. DOI: org/10.1016/j. scitotenv.2017.03.097

Hanafi S and Abo-El-Enein SA (1980), Surface properties of silicas produced by thermal treatment of rice husk ash, Thermochim. Acta 37: 137-143. DOI: org/10. 1016/0040-6031(80)80034-7

Huq SMI (2008), Fate of arsenic in irrigation water and its potential impacts on food chain In: Arsenic Contamination of Groundwater: Mechanism, Analysis, and Remediation, Ed. Ahuja S, Wiley, Hoboken, pp 23-49.

Huq SMI and Alam MD (2005), A Hand Book on Analyses of Soil, Plant and Water, Bangladesh Australia Center for Environmental Research, University of Dhaka, Dhaka.
Huq SMI and Shoaib JUM (2013), The Soils of Bangladesh, World soils book series, Springer, Dordrecht.

Huq SMI and R Naidu (2003), Arsenic in groundwater of Bangladesh: Contamination in the food chain In: Arsenic Contamination: Bangladesh Perspective, Ed. Ahmed MF, ITN Centre, Bangladesh University of Engineering and Technology, Dhaka, pp 203-226.

Igwebike-ossi CD (2017), Elemental analysis of rice husk using proton-induced X-ray emission (PIXE) spectrometric technique, Int. J. Appl. Chem. 12(3): 281-291.

Kabata-Pendias A ( 2011), Trace Elements in Soils and Plants, $4^{\text {th }}$ Ed., CRC Press, Boca Raton. DOI: org/10.1201/9781420039900

Leksungnoen P, Wisawapipat W, Ketrot D, Aramrak S, Nookabkaew S, Rangkadilok N and Satayavivad J (2019), Biochar and ash derived from silicon-rich rice husk decrease inorganic arsenic species in rice grain, Sci. Total Environ. 684: 360-370. DOI: org/10. 1016/j.scitotenv.2019.05.247

Li RY, Stroud JL, Ma JF, McGrath SP and Zhao FJ (2009), Mitigation of arsenic accumulation in rice with water management and silicon fertilization, Environ. Sci. Technol. 43: 3778-3783. DOI: org/10.1021/es803643v

Limmer MA, MannJ, Amaral DC, Vargas R and Seyfferth AL (2018), Silicon-rich amendments in rice paddies: Effects on arsenic uptake and biogeochemistry, Sci. Total Environ. 624: 1360-1368. DOI: org/10.1016/ j.scitotenv.2017.12.207

Liu WJ, McGrath SP and Zhao FJ (2014), Silicon has opposite effects on the accumulation of inorganic and methylated arsenic species in rice, Plant Soil 376: 423-431.

Luxton TP, Tadanier CJ and Eick MJ (2006), Mobilization of arsenite by competitive interaction with silicic acid, Soil Sci. Soc. Am. J. 70(1): 204-214. DOI: org/10.2136/sssaj2005.0101

Ma JF and Yamaji NA (2015), Cooperative system of silicon transport in plants, Trends Plant Sci. 20(7): 435-442. DOI: org/10.1016/j.tplants.2015.04.007

Ma JF, Tamai K, Yamaji N, Mitani N, Konishi S, Katsuhara M, Ishiguro M, Murata Y and Yano M (2006), A silicon transporter in rice, Nature 440: 688-691. 
Ma JF, Yamaji N, Mitani N, Xu XY, Su YH and McGrath SP (2008), Transporters of arsenite in rice and their role in arsenic accumulation in rice grain, Proc. Natl. Acad. Sci. 105(29): 9931-9935. DOI: org/10.1073/ pnas.0802361105

Ma JF, Goto S, Tamai K andIchii M (2001a), Role of root hairs and lateral roots in silicon uptake by rice, Plant Physiol. 127: 1773-1780. DOI: org/10.1104 /pp.010271

Ma JF, MiyakeY and Takahashi E (2001b), Silicon as a beneficial element for crop plants In: Silicon in Agriculture, Eds. Datnoff LE, Snyder GH and Korndorfer GH, Elsevier Science, Amsterdam, pp 17-39. DOI: org/10.1016/S0928- 3420(01) 80006-9

Ma R, Shen JL, Wu JS, Tang Z, Shen QR and Zhao FJ (2014), Impact of agronomic practices on arsenic accumulation and speciation in rice grain, Environ. Pollut. 194: 217-223. DOI: org/10.1016/j. envpol.2014.08.004

Mahimairaja S, Bolan NS, Adriano DC and Robinson B (2005), Arsenic contamination and its risk management in complex environmental settings, $A d v$. Agron. 86: 1-82. DOI:: org/10.1016/S00652113(05)86001-8

Mansaray KG and Ghaly AE (1998), Agglomeration characteristics of silica sand-rice husk ash mixtures at elevated temperatures, Energy Sources 20(7): 631-652. DOI: org/10.1080/00908319808970083

Martin M, Bonifacio E, Hossain KMJ, Huq SMI and Barberis E (2014), Arsenic fixation and mobilization in the soils of the Ganges and Meghna floodplains. Impact of pedoenvironmental properties, Geoderma 228-229: 132-141.

Martin M, Stanchi S, Hossain KMJ, Huq SMI and Barberis E (2015), Potential phosphorus and arsenic mobilization from Bangladesh soils by particle dispersion, Sci. Total Environ. 536: 973-980. DOI: org/10.1016/j. scitotenv.2015.06.008

Meharg AA and Rahman M (2003), Arsenic contamination of Bangladesh paddy field soils: Implications for rice contribution to arsenic consumption, Environ. Sci.
Technol. 37(2): 229-234. DOI: org/10.1021/ es0259842

Meharg AA, Abedin MJ, Rahman MM, Feldmann J, Cotter-Howells J and Cresser MS (2001), Arsenic uptake and metabolism in Bangladesh rice varieties, $1^{\text {st }}$ International Workshop on Arsenic in the Asia-Pacific region: Managing arsenic for our future, Book of Abstracts, Adelaide, South Australia, pp 45-46,

Moreno-Jiménez E, Esteban E and Peñalosa JM (2012), The fate of arsenic in soil-plant systems In: Reviews of Environmental Contamination and Toxicology, Ed. Whitacre DM, vol. 215, Springer, New York, pp $1-37$.

Norton GJ, Dasgupta T, Islam MR, Islam S, Zhao FJ, Stroud JL, McGrath SP, Feldmann J, Price AH and Meharg AA (2010), Arsenic influence on genetic variation in grain trace-element nutrient content in Bengal Delta grown rice, Environ. Sci. Technol. 44: 8284-8288. DOI: rg/10.1021/es101487x

Parr JF and Sullivan LA (2005), Soil carbon sequestration in phytoliths, Soil Biol. Biochem. 37: 117-124. DOI: org/10.1016/j.soilbio.2004.06.013

Pati S, Pal B, Badole S, Hazra GC and Mandal B (2016), Effect of silicon fertilization on growth, yield, and nutrient uptake of rice, Commun. Soil Sci. Plant Anal. 47(3): 284-290.

Penido ES, Bennet AJ, Hanson TE and Seyfferth AL (2016), Biogeochemical impacts of silica-rich rice residue incorporation into flooded soils: Implications for rice nutrition and cycling of arsenic, Plant Soil 399: 75-87.

Roberts LC, Hug SJ, Dittmar J, Voegelin A, Kretzschmar R, Wehrli B, Cirpka OA, Saha GC, Ali MA and Badruzzaman ABM (2010), Arsenic release from paddy soils during monsoon flooding, Nat. Geosci. 3(1): 53-59.

Savant NK, Snyder GH and Datnoff LE (1997), Silicon management and sustainable rice production, $A d v$. Agron. 58: 151-199. DOI: org/10.1016/S0065-2113 (08)60255-2

Schoof RA, Yost LJ, EickhoffJ, Crecelius EA, Cragin DW, Meacher DM and Menze DB (1999), A market basket survey of inorganic arsenic in food, Food Chem. Toxicol. 37: 839-846. 
Seebold KW, Kucharek TA, Datnoff LE, Correa-Victoria FJ and Marchetti MA (2001), The influence of silicon on components of resistance to blast in susceptible, partially resistant, and resistant cultivars of rice, Phytopathol. 91: 63-69.

Seyfferth AL and Fendorf S (2012), Silicate mineral impacts on the uptake and storage of arsenic and plant nutrients in rice (Oryza sativa L.), Environ. Sci. Technol. 46: 13176-13183. DOI: org/10.1021/es3025337

Seyfferth AL, Morris AH, Gill R, Kearns KA, Mann JN, Paukett M and Leskanic C (2016), Soil incorporation of silica-rich Rice husk decreases inorganic arsenic in rice grain, J. Agric. Food Chem. 64: 3760-3766. DOI: org/10.1021/acs.jafc.6b01201

Sommer M, Kaczorek D, Kuzyakov Y and Breuer J (2006), Silicon pools and fluxes in soils and landscapes-A review, J. Plant Nutr. Soil Sci. 169: 310-329. DOI: .org/10.1002/jpln.200521981

Stroevena P, Bui DD and Sabuni E (1999), Ash of vegetable waste used for economic production of low to high strength hydraulic binders, Fuel 78: 153-159.

Swain R and Rout GR (2018), Effect of silicon interaction with nutrients in rice, J. Exp. Biol. Agric. Sci. 6(4): 717-731.

Takahashi Y, Minamikawa R, Hattori KH, Kurishima K, Kihou N and Yuita K (2004), Arsenic behavior in paddy fields during the cycle of flooded and non-flooded periods, Environ. Sci. Technol. 38: 1038-1044. DOI: org/10.1021/es034383n

Teasley WA, Limmer MA and Seyfferth AL (2017), How rice (Oryza sativa L.) responds to elevated As under different Si-rich soil amendments, Environ. Sci. Technol. 51: 10335-10343.

Tripathia P, Tripathia RD, Singh RP, Dwivedia S, Goutama D, Shria M, Trivedia P and Chakrabarty D(2013), Silicon mediates arsenic tolerance in rice (Oryza sativa L.) through lowering of arsenic uptake and improved antioxidant defence system, Ecol. Eng. 52: 96-103. DOI: org/10.1016/j.ecoleng.2012.12.057

Wang H-Y, WenS-L, ChenP, ZhangL, Cen K and Sun G-X (2016), Mitigation of cadmium and arsenic in rice grain by applying different silicon fertilizers in contaminated fields, Environ. Sci. Pollut. Res. 23: 3781-3788.

Wickramasinghe DB and Rowell DL (2006), The release of silicon from amorphous silica and rice straw in Sri Lankan soils, Biol. Fertil. Soils 42: 231-240.

Wilding LP (1967), Radiocarbon dating of biogenetic opal, Sci. 156: 66-67. DOI: 10.1126/science.156.3771.66

Williams PN, Villada A, Deacon C, Raab A, Figuerola J, Green AJ, Feldmann J and Meharg AA (2007), Greatly enhanced arsenic shoot assimilation in rice leads to elevated grain levels compared to wheat and barley, Environ. Sci. Technol. 41: 6854-6859.

Williams PN, Islam MR, Adomako EE, Raab A, Hossain SA, ZhuY-G, Feldmann J and Meharg AA (2006), Increase in rice grain arsenic for region ns of Bangladesh irrigating paddies with elevated arsenic in groundwaters, Environ. Sci. Technol. 40: 4903-4908. DOI: org/10.1021/es060222i

Williams PN, Islam S, Islam R, Jahiruddin M, Adomako E, Soliaman ARM, Rahman GKMM, LuY, Deacon C, ZhuY-G and Meharg AA (2009), Arsenic limits trace mineral nutrition (Selenium, Zinc, and Nickel) in Bangladesh rice grain, Environ. Sci. Technol. 43: 8430-8436. DOI: org/10.1021/es901825t

Xu XY, McGrath SP, Meharg AA and Zhao F-J (2008), Growing rice aerobically markedly decreases arsenic accumulation, Environ. Sci. Technol. 42(15): 5574-5579. DOI: org/10.1021/es800324u 